\title{
カチオン電着塗装におけるクレータリング 発生機構

\section{Cratering Mechanism of Cationic Electrodeposition Primer over Precoated Steel Sheets}

Takahiro KuBota and Masaaki YamaSHITA

\begin{abstract}
Synopsis :
Cationic electrodeposition primers have been widely adopted by automobile companies due to their advantages with regared to application and corrosion resistance. However, under certain conditions, cationic electrodeposition primers can give craters over precoated steel sheets. Therefore, it is important to establish the exact mechanism of cratering from the viewpoint of cratering control.

In this study, resistance-time profile which were calculated by means of measured current and voltage at the initial stage of electrodeposition were investigated using digitized measurements to record data over millisecond time scales. Uncured as-deposited paint film in the course of electrodeposition was observed by optical microscope, and defects remained in the deposited film at the end of electrodeposition was also observed during curing process by optical microscope. The results indicate that electrodeposited paint film is ruptured by violent hydrogen gas generated locally during electrocoating, and the defects remaind in the deposited film at the end of electrodeposition cause cratering after curing paint film.

Key words : cationic electrodeposition primer; cratering; organic-silicate composite coated steel sheet; zinc and zinc alloy coated steel sheet; resistance-time profile.
\end{abstract}

\section{1. 緒言}

カチオン電着塗装は, 操作性・耐食性に優れることか ら，自動車車体の下塗り塗装として広く実用化されてい る.しかし，カチオン電着塗装では，塗装条件や被塗物 である表面処理鋼板の種類によっては，ピンホール状あ るいはクレーター状の塗装欠陷が発生することがあり， これらの塗装欠陷は, 最終的な塗装の什上り外観を劣化 させるため問題となる，さらに，近年，自動車車体の耐 食性问上を目的として，业鉛系めっき鋼板や有機複合被 覆鋼板 ${ }^{1) 2)}$ の使用比率が増加する傾们にあるが，これら の表面処理鋼极は，冷延鋼板と比較して耐クレータリン グ性が劣るため, クレーターの発生をいかに抑制するか という観点からも, カチオン電着塗装のクレータリング 発生機構の解明は, 重要な課題である.

クレータリング発生機構については, 既にいくつかの 報告3) 6) があり, 高電压で電着塗装を行った場合に発 生する火花放電により, 局部的に塗膜の硬化が進み, 焼 付工程における熱流動が阻等され，クレーターが形成さ
れることが考えられている.また，電着塗装中の回路に 流れる電流の時間変化とクレータリングとの関連につい て報告78) されている. しかしながら，クレータリング 発生機構については, 十分には解明されていない.

本報では, 電着塗装初期過程に打ける電流・電压から 抵抗の時間変化を求め, さらに, 電着塗装途中で引き上 げた末硬化の電着膜について光学顕微鏡観察を行うこと により，クレータリング発生機構について検討したので 報告する.

\section{2. 実 験 方 法}

\section{$2 \cdot 1$ 試料}

供試材としては, 最近開発された有機複合被覆鋼 板 ${ }^{1) 2}$, 冷延鋼板 (CRS), $\mathrm{Zn}-\mathrm{Ni}$ 合金めっき鋼板 ( $\left.\mathrm{EZN}\right)$, 合金化溶融亜鉛めっき鋼板 (GA) を用いた。供試材の 皮膜構成の詳細を Table 1 に示す. 塗装の前処理とし て，日本パーカライジング(株)製 PB-L3020でりん酸 塩処理を施したが, 一部の実験ではアルカリ脱脂のみを 行った。カチオン電着塗料は, 日本ペイント(株)製パ

半成元年 9 月本会講演大会にて発表 (Received Nov. 22, 1990)

* NKK 鉄銅研究所 (Steel Research Center, NKK Corporation, 1 Kokan-cho Fukuyama 721) 
Table 1. Film composition of the substrates.

\begin{tabular}{c|l}
\hline \multicolumn{1}{c|}{ Materials } & \multicolumn{1}{c}{ Film composition } \\
\hline $\begin{array}{l}\text { Organic-silicate composite } \\
\text { coated steel }\end{array}$ & $\begin{array}{c}\text { Organic-composite coating } / \text { chromate } \\
\text { coating } / \mathrm{Zn}-12 \% \mathrm{Ni}, 20 \mathrm{~g} / \mathrm{m}^{2}\end{array}$ \\
Cold rolled steel & None \\
$\mathrm{Zn}-\mathrm{Ni}$ electroplated steel & $\mathrm{Zn}-12 \% \mathrm{Ni}, 20 \mathrm{~g} / \mathrm{m}^{2}$ \\
Galvannealed steel & $\mathrm{Zn}-10 \% \mathrm{Fe}, 60 \mathrm{~g} / \mathrm{m}^{2}$ \\
\hline
\end{tabular}

ワートップU-100を標準条件で使用した。

\section{$2 \cdot 2$ 電着塗装}

各供試材の端部および亭面は粘着テープでシールし， 電着塗装される面積を一望 $(56 \times 128 \mathrm{~mm})$ とした。電 着塗装開始から $30 \mathrm{~s}$ で最終負荷電压に到達するようス ロープ通電を行い, トータルの電着塗装時閂は $180 \mathrm{~s}$ と

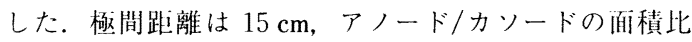
は $1 / 2$ とした。電着塗装中の回路に流れる電流・電压: の测定は，横河電機(株)製のアナライジングレコーダ

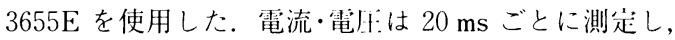
$\ulcorner V=I R 」 の$ 関係から抵抗の時閫变化を求めた。

\section{$2 \cdot 3$ 電着塗膜の観察}

電着塗装を途中で中断し, 供試材を水洗・冷風乾燥し たのち，未硬化な析出塗膜の表目状態を光学:顕微鏡で観 祭することにより，電着塗装中の析出塗膜の成言過程を 検討した。また， $180 \mathrm{~s}$ 間電着塗装後，供試材を水洗・ 冷風乾燥し， $180^{\circ} \mathrm{C} に$ 保温したホットプレートトに放㯰 し，加熱過程での電着涂膜を光器顕微鏡で観祭した。

さらに，クレーターの原闪となる析出涂膜中の欠陷部 を，来硬化な状態のまま $N, N$-ジメチルホルムアミ ド (DMF) により塗膜を溶解し，涂膜溶解後の表面を光 学顕微鏡および走查型電子顕微鏡 (SEM) で観祭した。

\section{3. 実 験 結 果}

\section{$3 \cdot 1$ 耐クレータリング性}

各供試材の耐クレータリング性を Table 2 に示す. 負荷電压が比較的低い（200 V) 場令には，GA を除いて は,いずれの供試材にもクレーターは形成されなかった。

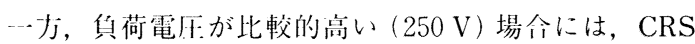
を除くすべての供武材にクレーターが発生した。

Table 2. Anti-cratering properties of the substrates.

\begin{tabular}{l|cc}
\hline \multirow{2}{*}{ Materials } & \multicolumn{2}{|c}{ Crater density $\left(\mathrm{cm}^{-2}\right)$} \\
\cline { 2 - 3 } & $200 \mathrm{~V}$ & $250 \mathrm{~V}$ \\
\hline Organic-silicate composite coated steel & 0 & 31 \\
Cold rolled steel & 0 & 0 \\
Zn-Ni electroplated steel & 0 & 35 \\
Galvannealed steel & 26 & 87 \\
\hline
\end{tabular}

なお，250 V で電着塗装を行う際に，実験室の照明を 消灯し, 真っ暗な状態で火花放電の発生の有無について 詳細に観祭したが，GAのように多くのクレーターが発 生した場今でも，従来報告されている3) -6) ような火花 放電は全く観察されなかった。

\section{$3 \cdot 2$ 電着塗装時の電流の時間変化}

各供試材の電着塗装の初期過程（初めの約 $35 \mathrm{~s}$ ）にお ける電流の時間变化を Fig. 1〜3 に示す。電流の時間変 化には，佐藤7)の報告にあるように複数のピークが観祭 され，有機複合被覆鋼板では二つ， $\mathrm{CRS} \cdot \mathrm{EZN} \cdot \mathrm{GA}$ では三つのピークが観祭された。特に，クレーターの発 生した供試材では，通電開始から約 $30 \mathrm{~s}$ 後に観察され た最終ピーク (以下 $i_{B}{ }^{7)}$ と略記する) 付近で, 電流值が ふらつきながら変化した (Fig. 1，2).一方，クレーター の発生しなかった CRS の場命には， $i_{B}$ の高さも低く， 電流值の変化も滑らかであった (Fig. 3).

\section{$3 \cdot 3$ 電流塗装時の抵抗の時間変化}

$\mathrm{EZN}$ を $250 \mathrm{~V}$ で電着塗装した場令の，初期過程にお ける抵抗の時間変化を Fig. 2 に亦す。電着塗装開始㨁

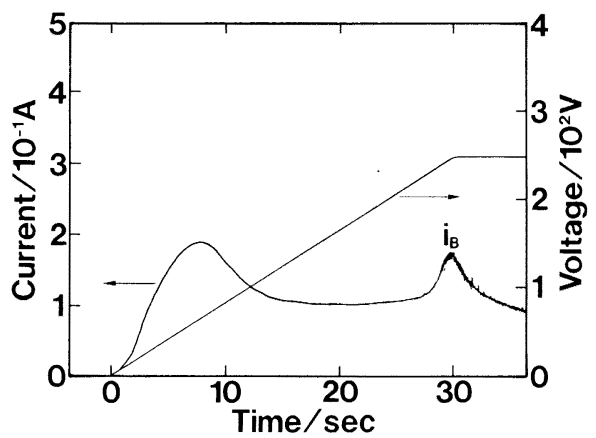

Fig. 1. Current-time profile at the initial stage of cathodic electrocoating of organic-silicate composite coated steel sheet.

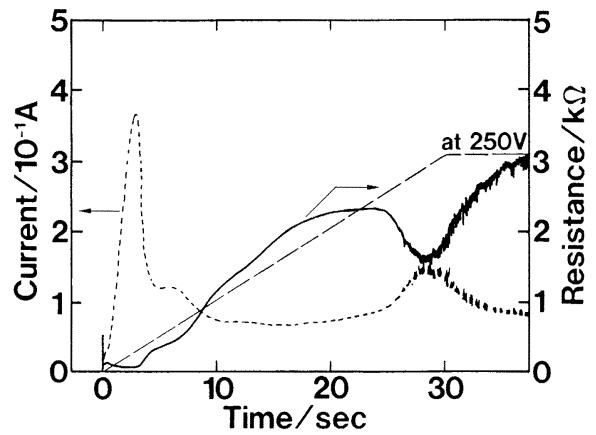

Fig. 2. Current-time and resistance-time profiles at the initial stage of cathodic electrocoating of $\mathrm{Zn}-\mathrm{Ni}$ electroplated steel sheet. 


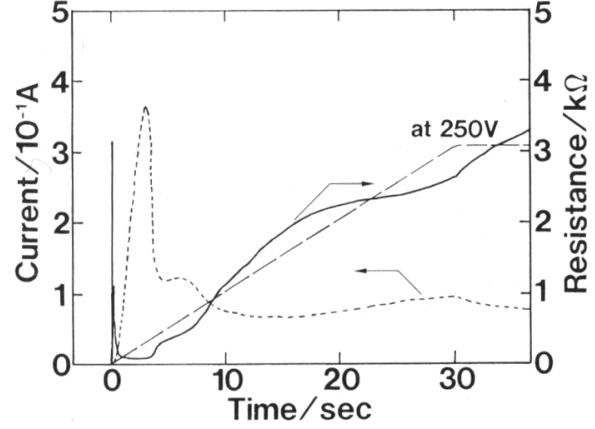

Fig. 3. Current-time and resistance-time profiles at the initial stage of cathodic electrocoating of cold rolled steel sheet.

後に抵抗值に鋭い立上がりが認められたが，その後約 3 $\mathrm{s}$ 間は抵抗值は増加しなかった。 $3 \mathrm{~s}$ から約 $24 \mathrm{~s}$ まで は，抵抗值が徐々に増加し， $i_{B}$ が記録された約 $28 \mathrm{~s}$ 付 近では，逆に抵抗值の減少が認められた。その後，抵抗 值はふらつきながら再び増加した。

CRS を $250 \mathrm{~V}$ で電着塗装した場合の, 初期過程にお ける抵抗の時間変化を Fig. 3 に示す. 電着塗装開始か ら約 $25 \mathrm{~s}$ 付近までは, Fig. 2 に示した EZNの場合と ほほ同様の抵抗の時間変化を示したが, 昇圧が終了する $30 \mathrm{~s}$ 付近でも抵抗值の減少は認められず, その後も滑 らかな抵抗值の増加が継続した。

\section{$3 \cdot 4$ 析出塗膜の観察}

Fig. 2 および Fig. 3 に示したように, 電着塗装中の 抵抗の時間変化には，いくつかの段階の存在が示唆され たため,これらの各段階における析出塗膜の表面を光学: 顕微鏡で観察することにより，抵抗の時間変化とクレー ター生成との関連について検討した。

抵抗の時間変化の各段階における, EZN 上の析出塗 膜の光学顕微鏡写真を Photo. 1 に示す. 電着塗装開始 直後から抵抗值が停滞する約 $3 \mathrm{~s}$ 間 (A 段階) の表面外 観は, りん酸塩処理後の状態と同一であり, 電着塗膜は

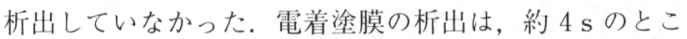
ろで抵抗值が増加する B 段階で，初めて観察された。 その後, 約 $24 \mathrm{~s}$ (C 段階) までは, 析出塗膜が均一に成 長するのが観察されたが， $i_{B}$ のピークが観察された約 $28 \mathrm{~s}$ 付近 (D 段階) では, 多くのボイド状の塗膜欠陥が 認められた。そして，この D 段階で観察されたものと 同様のボイド状の塗膜欠陷は, 電着塗装終了後の析出塗 膜中にも数多く認められた。有機複合被覆鋼板や GA でも，ほほ同様の電着塗膜の析出過程が観察された。

CRS に電着塗装を行った場合の, 抵抗の時間変化の
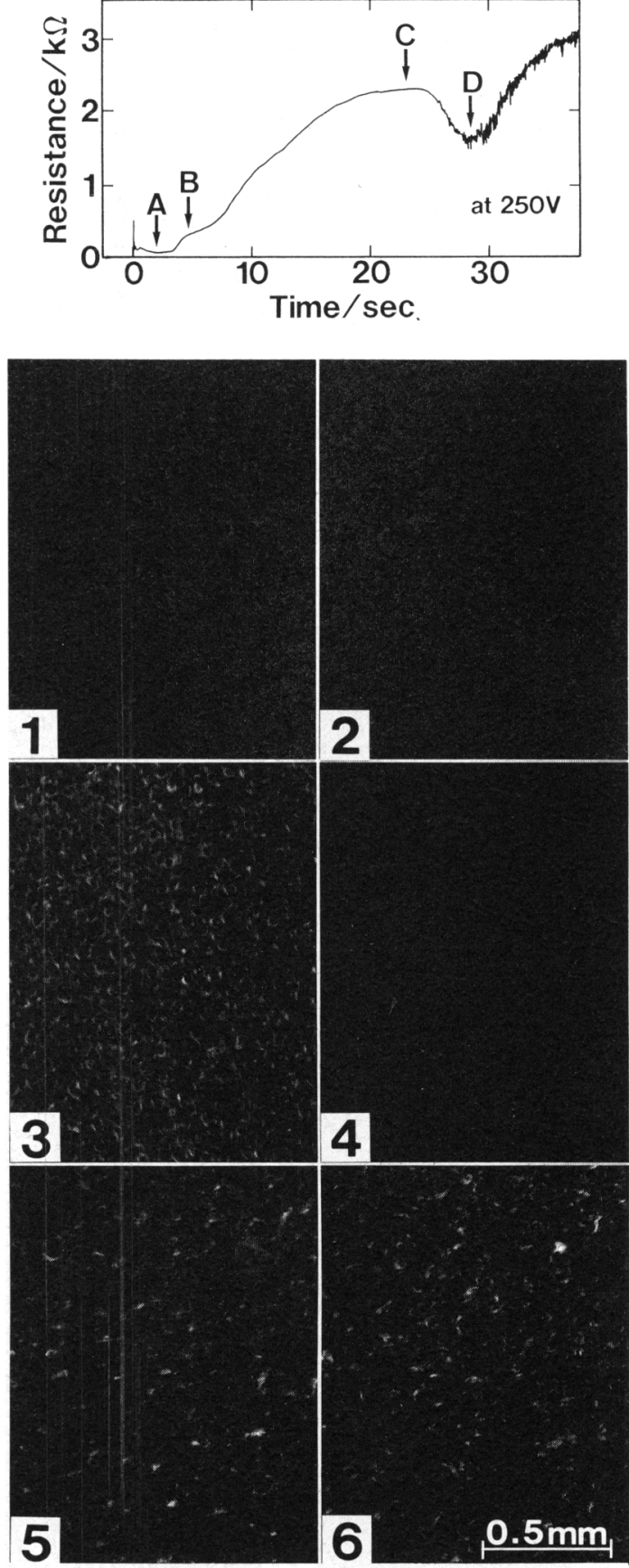

1: As phosphated $2:$ At A stage $3:$ At B stage $4:$ At C stage 5: At D stage 6: At the end of electrodeposition

Photo. 1. Optical micrographs of uncured electrodeposited film over $\mathrm{Zn}-\mathrm{Ni}$ electroplated steel sheet. 


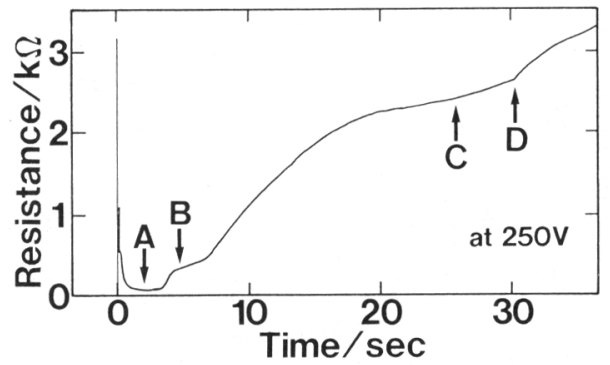

各段階に抢ける析出塗膜の光学影微鏡写真をPhoto. 2 に示す。EZNの場合と同様に，A 段階では電着染膜の 析出は認められなかった。また，B 段階から C 段階に 至るまでの析出塗膜の表面外観は，EZNの場合とほほ 同様であったが，昇圧終了付近の D 段階㧍よび電着染 装終了後の析出塗膜には，ボイド状の塗膜欠陥が全く認 められなかった。

\section{$3 \cdot 5$ 析出塗膜の加熱硬化過程}

電着塗装終了後の有機複合被覆鋼板上に形成されたボ イド状の滁膜欠陥の加熱硬化過程での変化を光学顕微鏡
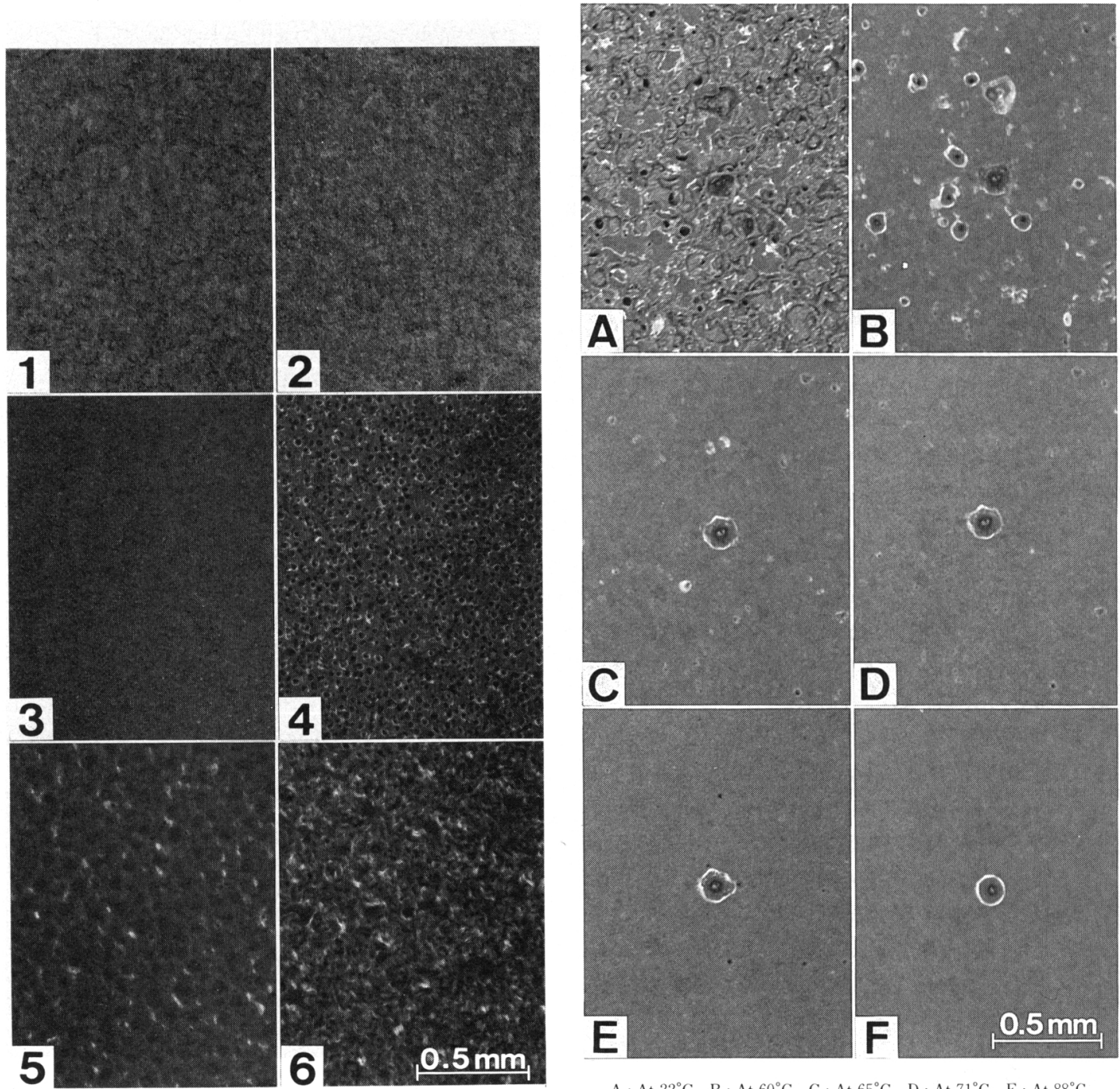

A : At $22^{\circ} \mathrm{C} \quad$ B : At $60^{\circ} \mathrm{C} \quad$ C : At $65^{\circ} \mathrm{C} \quad$ D : At $71^{\circ} \mathrm{C} \quad$ E : At $88^{\circ} \mathrm{C}$ F : At $177^{\circ} \mathrm{C}$

Photo. 3. A crater formation process during curing cathodic electrocoated film on the organicsilicate composite coated steel sheet. deposited film over cold rolled steel sheet. 
で観祭した (Photo. 3). 電着塗装終了後の表面には, 大きなボイド状欠陥の他にも周用に比較的小さな気孔が 観察されたが，鋼板の温度の上昇とともに電着塗膜の熱 流動により，これらの小さな気孔は徐々に消滅し，最終 的には，大きなボイド状欠陥のみからクレーターが形成 されることが観察された，EZNや GA でも同様の結果 が得られた。

\section{$3 \cdot 6$ りん酸塩処理の影響}

りん酸塩処理を行った場合と行わなかった場合につい て，それぞれ比較的高い電压 $(240 \mathrm{~V})$ で電着塗装を行 い，耐クレータリング性を評価した結果を Table 3 に 示す. EZNや GA に関しては，りん酸塩処理を行わな い場合の方が酎クレータリング性が良好であった。一方, 有機複合被覆鋼板の場合は, 垔鉛系めっき鋼板の場合と 比較してりん酸塩処理の影響は少なかった。

EZN の，りん酸塩処理を行った場合と行わなかった 場合の電流の時間変化および抵抗の時間変化を Fig. 4 に示す。りん酸塩処理を行わなかった場合には, $30 \mathrm{~s}$ 付近での抵抗值の減少が認められず，また， $i_{B}$ の高さ

Table 3. Anti-cratering properties of the substrates with and without phosphating.

\begin{tabular}{l|c|c}
\hline \multirow{2}{*}{ Materials } & \multicolumn{2}{|c}{ Crater density $\left(\mathrm{cm}^{-2}\right)$} \\
\cline { 2 - 3 } & $\begin{array}{c}\text { with } \\
\text { phosphating }\end{array}$ & $\begin{array}{c}\text { without } \\
\text { phosphating }\end{array}$ \\
\hline Organic-silicate composite coated steel & 32 & 26 \\
Cold rolled steel & 0 & 0 \\
Zn-Ni electroplated steel & 41 & 1 \\
Galvannealed steel & 89 & 9 \\
\hline
\end{tabular}

Applied voltage : $240 \mathrm{~V}$

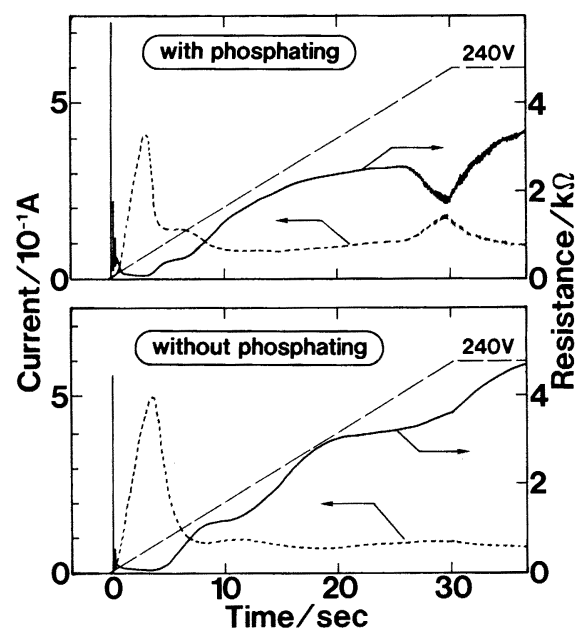

Fig. 4. Current-time and resistance-time profiles at the initial stage of cathodic electrocoating of $\mathrm{Zn}-\mathrm{Ni}$ electroplated steel sheet.
もりん酸塩処理を行った場合よりも低く，電流および抵 抗の変化も滑らかであった。 さらに，電着塗装開始值後 に抵抗值が停滞する A 段階の時間が，りん酸塩処理を 施さなかった場合（約 $5 \mathrm{~s}$ ) の方が，りん酸塩処理を行っ た場合（約 $3 \mathrm{~s}$ ) よりも長かった。

有機複合被覆鋼板の，りん酸塩処理を行った場合と行 わなかった場合の電流の時間変化および抵抗の時間変化 を Fig. 5 に示す. EZN の場合と異なり，りん酸塩処理 の有無は, 電流の時間変化および抵抗の時間変化にほと

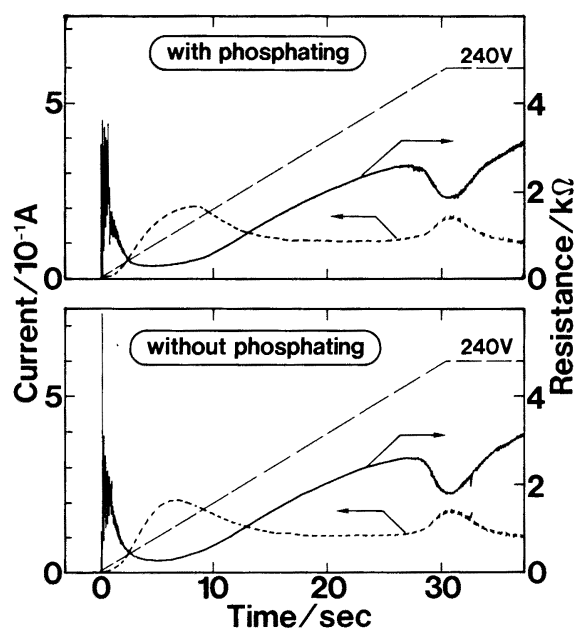

Fig. 5. Current-time and resistance-time profiles at the initial stage of cathodic electrocoating of organic-silicate composite coated steel sheet.

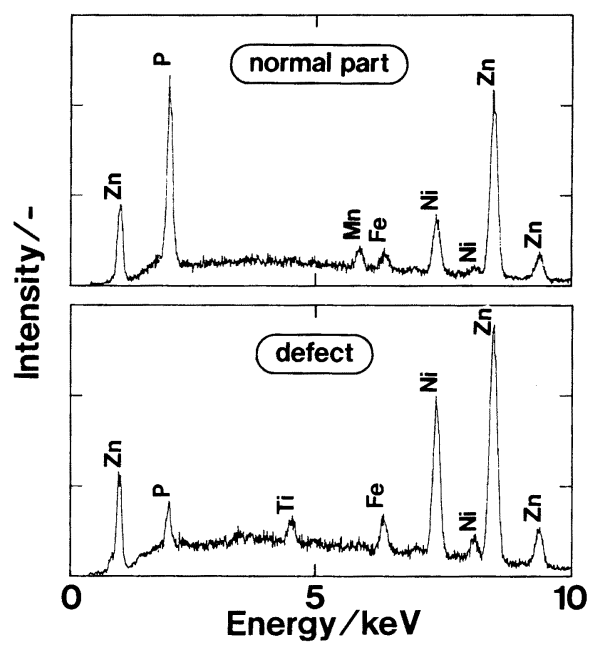

Fig. 6. EDX analysis of cathodic electrocoated $\mathrm{Zn}-\mathrm{Ni}$ electroplated steel sheet after removing deposited film by DMF. 


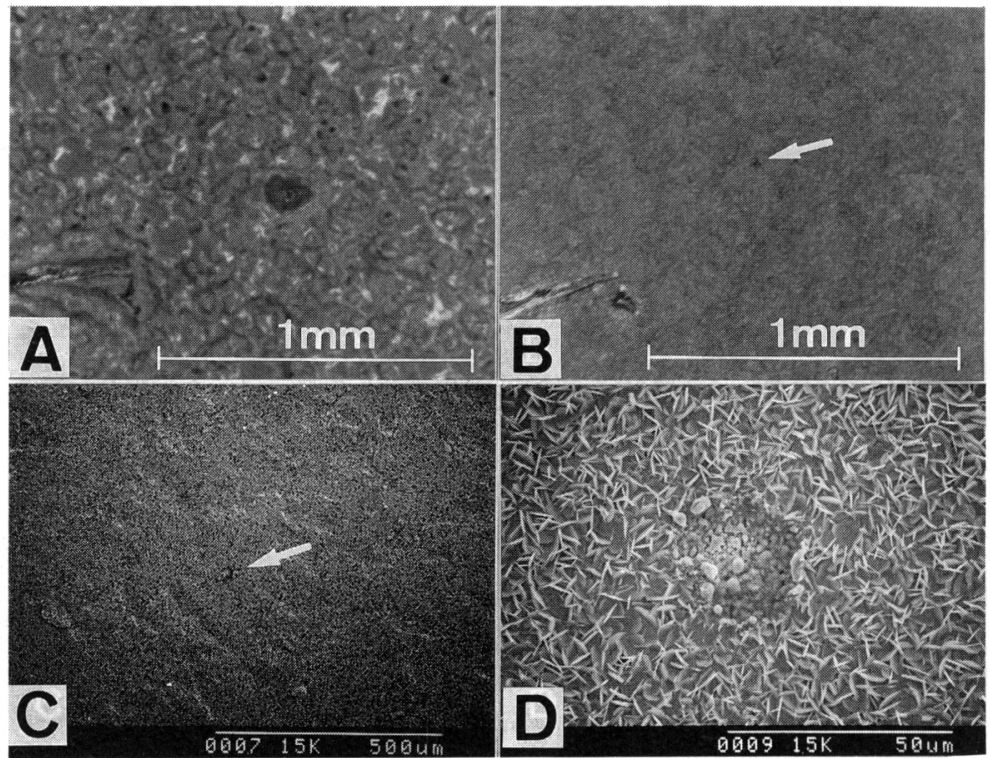

A : Optical micrograph of as-deposited electrocoated film

B : Optical micrograph after removing electrocoated film

C : SEM micrograph after removing electrocoated film

D : SEM micrograph after removing electrocoated film

Photo. 4. Optical micrographs and SEM micrographs of a defect in cathodic electrocoated film on $\mathrm{Zn}-\mathrm{Ni}$ electroplated steel sheet.

んど影響を及ぼさかった。

\section{$3 \cdot 7$ クレーター形成の起点}

電着塗装終了後, EZN 上に形成された析出塗膜のボ イド状欠陥部を，未硬化な状態のままDMFにより溶解 し，光学顕微鏡および SEM で観察した (Photo. 4). 塗 膜溶解後のボイド状欠陷の中心部の表面には, 従来報 告4)5) されている硬化した電着塗料の核は認められず, りん酸塩皮膜の欠陷が観祭された。欠陷の中心部および 拮囲の健全部をエネルギー分散型 X 線分光器 (EDX) で分析した結果を Fig. 6 に示す。欠陉の中心部では, 健全部と比較して $\mathrm{P}$ および $\mathrm{Mn}$ の強度が低く, $\mathrm{Ti}$ の強 度が高かった，有機複合被覆鋼板の場合には，DMFに より有機複合皮膜も溶解したために, ボイド状欠陷の中 心部の状態については, 明確にすることができなかった。

\section{4. 考察}

\section{$4 \cdot 1$ クレーターの形成過程}

佐藤 ${ }^{7)}$ は， $i_{B}$ と耐クレータリング性とに相関がある ことを認めたが， $i_{B}$ の発現機構については，十分な考 察をしなかった。筆者らは，測定した電流・電庄から抵 抗の時間变化を求めることにより，電着塗膜の析出挙動 とタレータリングの形成過程についてより詳練な検討を
行った.

電流および電圧から計算した抵抗は, 主に析出した電 着塗膜の抵抗, 電着塗料の浴抵抗, 鋼板の抵抗掞よび鋼 板上の表面処理皮膜（例えばりん酸塩皮膜，めっき皮膜， 有機複合皮膜等）の抵抗加構成されるものと考えられ るが, 電着塗装中の電着塗料・鋼板・表面処理皮膜に起 因する抵抗の変化は，ほとんど無視できることから， Fig. 2〜5 で観察された抵抗の変化は, 析出した電着塗 膜の成長や破壊によるものと考えられる。しかし，電着 塗装開始直後の抵抗値の大きな变化は, 通電直後の供試 材/電着塗料界面の状態が不安定なこと, および通電直 後の電流・電圧值が共に小さいことに起因する測定值の ばらつきと考えられる，従って，通電開始直後の抵抗の 変化は，電着塗料の析出挙動とは無関係である.

Fig. 2，3 で観察された，通電開始から数秒間続く A 段階での抵抗值の停滞は, 電着塗料/供試材界面の $\mathrm{pH}$ が十分に高まっていないために, 電着塗膜の析出が起こ らなかったものと考えられる。B段階で観察された 2 回目の抵抗值の上昇は, $\mathrm{pH} の$ 上昇による電着塗膜の析 出の開始を意味するものと考えられる。 その後, B 段 階から C 段階までは, 析出塗膜の均一な成長が継続す るものの, タレーターが形成される場合には，昇压終了 


\section{A stage: no deposition \\ B stage: \\ C stage: thickening of deposited film \\ D stage: rupture of deposited film \\ End: void remaining \\ After curing: cratering} beginning of deposition

Fig. 7. Schematic diagram of mechanism of cathodic electrocoating cratering.

付近の D 段階で, 岉部的に発生した水素ガスによりいっ たん析出した電着塗膜が破壊され, 破壊に起因する新た な通電経路の形成により抵抗が減少し， $i_{B}$ が観察され たものと考えられる。ささらにこの新たな通電経路での 電着塗膜の再析出，および別の場所での析出塗膜の破壊 が繰り返されることにより，D段階から電着塗装終了 までの閏，抵抗值がふらつきながら増加したものと考え られる。

このような過程を経て析出塗膜中に形成された，ある 大きさ以上のボイド状の塗膜欠陷は, 加熱硬化過程での 熱流動でも被㠅されないために，クレーターが塗膜中に 形成されるものと考えられる(Photo. 3).

以上述べたクレーター形成過程を, Fig. 7 に模式的に まとめた。

\section{$4 \cdot 2$ クレーターの発生起点}

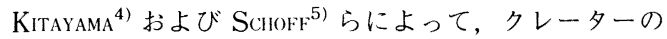
起点となるは，火花放電により硬化した塗膜であること が報告されているが, 本研究では Photo. 4 に示したよ うにこのような雓料の核は認められなかった。

Photo. 4 拉よび Fig. 6 の結果から, ボイド状の塗膜 欠陷中心部の EZN 表而では, 健全なりん酸塩皮膜と比 較して, EDX の $\mathrm{P}$ の強度が低く, Mnのピークが観察 されないため,この部分には，りん酸塩皮膜がほとんど 形成されていないものと考えられる.また，この部分で
Tiのピークが観祭されたことから，りん酸塩处理の表 面調整の段階で， $\mathrm{TiO}_{2}$ コロイドが部分的に凝集・付着 し、りん酸塩皮膜が形成されなかったものと推定される.

りん酸塩処理された塗装素材表而には電気抵抗の小さ い部分と大きい部分が你在し，水の電気分解が電気抵抗 の小さい部分 (欠陷部) では起こりやすく，抵抗の大き い部分（健苹なりん酸塩皮膜）では起こりにくいため, 電着淦装の息荷電压が大きくなった場介には，久陷部で 勿部的に水素ガスが激しく発生し，これが起点となって 析出した電着塗膜を破壞するものと推定される。また， りん酸塩処理を施さない覀鉛系めっき鋼柲や，亚鉛系 めっき鋼板と比較して緻密なりん酸塩皮膜が形成される CRS の場介には，表而の通電性が均一なため，水素ガ スの発生が局部的に激しく起こることが少なく，耐ク レータリング性が良好であったものと考えられる。

一方，負荷電压が低い場命には，通電性の不均一な場 所が存在しても，流れる電流が小さいために，水素ガス の発生量が少なく，析出塗膜の大きな破壞には弚らな かったものと考えられる.

仿機複今被覆鋼板のクレーター発生起点については, 十分な解明ができなかったが，抢そらくミクロな膜厚の 不均…さどが起点となるものと推定される.

\section{$4 \cdot 3$ 有機複合被覆鋼板と亜鉛系めつき鋼板での電着塗 膜析出挙動の相違}

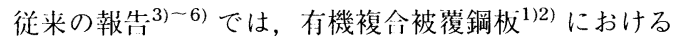
電着塗膜の析出挙動については検討されていなかったの で，有機複令被覆鋼板と亜鉛系めっき鋼板での電着塗膜 析出挙動の相違について考祭した。

Fig. 4 と Fig. 5 の抵抗の時閪变化を比較した場令, 電着塗膜の析出が開始される以前の A 段階での抵抗が, 有機複介被覆鋼板の方が大きい。この理由としては, 有 機複令被覆鋼极は，表而に均一一な存機複命皮膜が形成さ れているのに対し，EZN 鋼枚の場命は，りん酸塩皮膜 で完苹に被覆されていない部分が你在するためと考えら れる。この部分では，相対的に電流密度が高く，局部的 に $\mathrm{pH}$ が上昇し，比較的早い時間に電着塗膜の析出が開 始するものと考えられる。これは，りん酸塩皮膜のない $\mathrm{EZN}$ で，A 段階の時間が，りん酸塩皮膜のある場令よ りも产くなったことからも説明される.

さらに，存機複令被蕧鋼柲の場命には，表而にりん酸 塩皮膜が形成されないため，りん酸塩処理の有無が湫ク レータリング性に影響を及ぼさなかったものと推定され る。なお，有機複合被覆鋼板の場命には，りん酸塩皮膜 が形成されなくても，十分な塗料密着性，耐食性を存す ることが確認されており ${ }^{122)}$ ，実用上の問題はない。 


\section{$4 \cdot 4$ 放電現象に関する考察}

筆考らは，顔料を含有した電着塗料をそのまま使用し たため, $\mathrm{HART}^{3)} や \mathrm{SMITH}^{6)}$ のように透明な電着塗料を用 いた場命と比較して，電着塗装中の放電を直接観祭する ことはやや困難であったものと考えられる。しかし，市 販の電着塗料をそのまま使用した場令でも放電を観察し た報告 ${ }^{3)}$ があることから，本研究においても放電が発生 した場合には，これを観祭することは叮能であったと考 える、また， Sмттн $^{6)}$ は，いったん，比較的低い電圧で 薄く電着塗装を施し, 加熱することなく再度高電圧で電 着塗装を行った場合には，放電が観祭されなかったと報 告している．本研究では， $i_{B}$ が観察される直前の $\mathrm{C}$ 段 階における加熱硬化後の膜厚は約 $4 \mu \mathrm{m}$ であり，C段階 以降では放電が発生していないということは， SмITH $^{6)}$ の結果と一致しているものと考えられる.

$\mathrm{HART}^{3)}$ は，目視観察により電着塗装中の CRS および GA の表面からは，どちらも均一にガスが発生したため， ガス発生はクレーターの原因ではないと報告している.

しかし, 本研究の結果から, クレーターの起点となるボ イド状の欠陥は, 目視での観察が网難なほど小さく, 従って, 目視によるガス発生の観祭結果からは，ガス発 生がクレータリングの原因ではないと断定することは不 订能であると考える。

HaRT $^{3)}$ ， Kitayama ${ }^{4)}$ および Smith $^{6)} ら の$ 実験では, ス ロープ通電ではなく瞬間通電 (ドカン通電) で電着塗装 を行ったために，本研究におけるクレーター発生機構と は買なる結論が得られたものと推定される，確かに，瞬 閪通電の場令には，激しいガスの発生とともに火花放電 が観祭されることから，放電がクレータリングの原因と なることは十分考えられる。しかし，実際の自動車車体 を電着塗装する際には，通常，車体が最初に電着槽に浸 漬される位置にアノードを配狊しておらず，遠くのア ノードと車体間の浴抵抗により, 最初の負荷電压はかな り低く,アノードと車体の間隔が狭まることにより徐々 に昇压される。従って, 本研究で行ったスロープ通電に よる電着塗装の方が，より実際の自動車ラインをよくシ ミュレートしているものと考えられることから，筆者ら の示したクレータリング発生機構の方が, 実際の自動車 ラインで発生しているクレータリング発生機構を, より 真実に近いかたちで説明できるものと考えられる.

\section{5. 結言}

電着塗装初期過程における電流・電圧から求めた抵抗 の時間変化，および，電着叙装途中で引き上げた未硬化 の電着塗膜の光学顕微鏡観祭を行い，表面処理鋼权のク レータリング発生機構について検討した結果，以下のこ とが判明した。

(1)クレーターの形成過程としては, 電着塗装中に いったん析出した塗膜が，局部的に激しく発生した水素 ガスにより破壊され，ボイド状の欠陷となり，ある大き さ以上の久陥は，加熱硬化過程でも熱流動により隠蔽さ れることなく，クレーターとなる。

（2）クレータリングの起点は，亜鉛系めっき鋼板の場 合には，りん酸塩皮膜の欠陥部等の通電性の良好な部分 であり，有機複合被覆鋼板の場命には，ミクロな膜厚が 不均一で，薄い部分と推定される。

( 3 ) 有機複合被覆鋼板の表面には，均一に有機皮膜が 存在するため，全面で電着叙膜の析出が開始するが，带 鉛系めっき鋼板には，りん酸塩皮膜で被覆されない部分 が存在し，この部分の電着叙装時の電流密度が相対的に 高いため, 局部的に $\mathrm{pH}$ が上昇し，比較的早く電着塗膜 の析出が開始する。また，有機複合被覆鋼板の表面には， りん酸䘏皮膜が形成されないため，りん酸塩処理の有無 は耐クレータリング性にほとんど影響を及的ささない．

(4) 自動車ラインをシミュレートしたスロープ通電で 電着塗装を行った場合には，火花放電は発生せず，従っ て, 火花放電がクレータリング原因となるのは, 瞬間通 電の場合に限定されると考えられる.

\section{文献}

1 ) $M$. Yamashita, $T$. Kubota, $T$. Watanabe, $Y$. Miyosawa and T. Nishimoto: SAE (1989), 890707

2 ) 渡辺 勉, 山下正明, 窪田隆公, 松田恭典, 相川誠, 计村 豊: NKK 技報, 127 (1989), p. 107

3 ) R. G. HART and H. E. TownSEnd: SAE (1983), 831818

4 ) $M$. Kitayama, $T$. Azami, $N$. Miura and $T$. Ogasawara: Trans. Iron Steel Inst. Jpn., 24 (1984), p. 742

5 ) C. K. Schoff and H.- J. Chen: JOCCA, 68 (1985), p. 185

6 ) $R$. E. SMiTh and $D . W$. Boyd: Journal of Coatings Technology, 60 (1988), p. 77

7 ) 佐藤 登, 田中侤生郎: 鉄と錫, 72 (1986), p. 1084

8 ) C. L. CoON and J. J. VinCENT: Journal of Coatings Technology, 58 (1986), p. 53 